\title{
EFEKTIVITAS PEMBELAJARAN STATISTIK DENGAN PENDEKATAN KETERAMPILAN MULTI REPRESENTASI UNTUK MENINGKATKAN HASIL BELAJAR MAHASISWA PGMI UNIPDU JOMBANG (EFFECTIVENESS OF STATISTIC LEARNING WITH MULTIPLE REPRESENTATION SKILL TO IMPROVE STUDENT'S ACHIEVEMENT IN PGMI UNIPDU JOMBANG)
}

\author{
Miftakhul Ilmi S. Putra \\ Universitas Pesantren Tinggi Darul 'Ulum \\ mifta.unipdu@gmail.com
}

\begin{abstract}
Abstrak
Penelitian ini bertujuan untuk menyelidiki pengaruh pendekatan keterampilan multi representasi dalam meningkatkan hasil belajar mahasiswa pada pembelajaran statistik. Sampel penelitian adalah mahasiswa Semester 3 Program Studi PGMI (Pendidikan Guru Madrasah Ibtidaiyah), Unipdu, Jombang. Penelitian dilaksanakan pada bulan Oktober-Desember 2014 menggunakan desain eksperimen dengan teknik pengumpulan data melalui tes kognitif, observasi, dan wawancara. Hasil penelitian menunjukkan bahwa pembelajaran dengan pendekatan keterampilan multi representasi dapat meningkatkan hasil belajar mahasiswa pada statistik pendidikan. Analisis data menunjukkan bahwa ada pengaruh hasil belajar statistik mahasiswa PGMI semester 3 antara sebelum dan sesudah diberikan Pendekatan Keterampilan Multi Representasi.
\end{abstract}

Kata kunci: Keterampilan Multi Representasi, Hasil Belajar

\begin{abstract}
This study was aimed to investigate the influence of learning with multiple representation skill to improve student's achievement in statistic. Students of $3^{\text {rd }}$ semester majoring in PGMI, Unipdu, Jombang, were subjected with the tested learning method. The study was conducted in October-Desember 2014 with experimental design. Students' performance was assesed through cognitive tests, observation, and interviews. Results of this study indicate that learning with multiple representation skill of learning to improve students' achievement in statistic. Data analysis showed that there was influence in students' learning outcomes in statistical study of $3^{\text {rd }}$ semester between before and after learning with multiple representation skill approach.
\end{abstract}

Keywords: Multiple Representation Skill, Learning Achievement

\section{PENDAHULUAN}

Dosen merupakan komponen yang sangat menentukan dalam implementasi suatu strategi pembelajaran. Keberhasilan implementasi suatu strategi tergantung pada kepiawaian dosen dalam menggunakan metode, teknik dan strategi pembelajaran. Salah satu masalah yang dihadapi dalam dunia 
pendidikan adalah masalah lemahnya proses pembelajaran. Dalam proses pembelajaran peserta didik kurang didorong untuk mengembangkan keterampilan berpikir. Proses pembelajaran di dalam kelas diarahkan kepada kemampuan peserta didik untuk menghafal informasi, peserta didik terbiasa untuk mengingat berbagai informasi tanpa dituntut untuk memahami informasi yang diingat itu dan menghubungkannya dengan kehidupan sehari-hari, akibatnya peserta didik hanya pintar tetapi miskin aplikasi. Situasi seperti ini juga terjadi pada mata pelajaran sains. Mata pelajaran sains belum dapat mengembangkan kemampuan peserta didik untuk berpikir kritis dan sistematis, karena strategi pembelajaran berpikir belum digunakan secara baik dalam proses pembelajaran.

Keterampilan berpikir tingkat tinggi dan memahami konsep perlu dilatihkan sejak dini kepada calon guru MI, karena menurut Piaget perkembangan intelektual dan kemampuan peserta didik akan meningkat melalui empat tingkat yang berbeda. Tiap tingkatan memiliki karakteristik dari kemampuan baru, yang diikuti pengorganisasian pemikiran peserta didik (Slavin, 1994). Keterampilan meneliti, keterampilan berpikir tingkat tinggi dan memahami konsep ini belum membudaya di Indonesia khususnya pada calon guru MI. Calon guru MI saat ini lebih banyak dilatih menghafal teori tanpa mengembangkan keterampilan berpikir mereka.

Melihat begitu pentingnya melatihkan keterampilan meneliti, keterampilan berpikir tingkat tinggi dan memahami konsep maka seyogyanya proses pembelajaran dilakukan dengan cara melatihkan anak sejak dini untuk melakukan penelitian, sehingga anak dapat memperoleh pengalaman langsung untuk mengembangkan kompetensi yang dimiliki dalam menjelajahi dan memahami alam sekitar secara ilmiah. Statistik diperlukan dalam kehidupan sehari-hari untuk memenuhi kebutuhan manusia melalui pemecahan masalah-masalah kontekstual sesuai dengan kehidupan nyata. Dalam penerapan pembelajaran perlu dilakukan secara bijaksana agar tidak berdampak buruk terhadap lingkungan.

Mata kuliah Pembelajaran Statistik di mata mahasiswa PGMI Unipdu Jombang adalah salah satu mata kuliah yang kurang diminati. Hal ini merupakan tantangan bagi dosen untuk mencari solusi bagaimana kegiatan pembelajaran menjadi bermakna dan diminati bagi mahasiswa. Para dosen harus berusaha menentukan pendekatan, model dan metode yang tepat agar materi yang disajikan dapat dimengerti dan dipahami serta para mahasiswa mengetahui kegunaan materi tersebut dalam kehidupan sehari-hari. Sehingga tercipta suasana pembelajaran yang menyenangkan, aktif, dan efektif.

Program Studi PGMI Unipdu Jombang adalah salah satu program studi yang baru berkembang di lingkungan kampus Unipdu Jombang, sehingga banyak tantangan dan kendala yang dihadapi untuk mempertahankan dan meningkatkan mutu akademik maupun non akademik. Apalagi input mahasiswa yang masuk ke PGMI Unipdu Jombang adalah mahasiswa yang memiliki latar belakang yang heterogen baik dari latar belakang ekonomi maupun latar belakang kompetensi dasar yang dimilikinya.

Peneliti adalah Dosen Unipdu Jombang sehingga tertarik untuk melakukan penelitian khususnya di PGMI Unipdu Jombang karena heterogenitas dari kelas tersebut dan tampak dari sikap para mahasiswa dalam belajar cukup beragam. Mahasiswa yang memiliki kemampuan tinggi merasa bosan ketika dosen memberikan penjelasan yang berulang-ulang, sedangkan mahasiswa yang 
berkemampuan rendah semakin terlihat kesulitan dalam mengikuti pembelajaran. Berdasarkan observasi awal yang dilakukan peneliti, beberapa permasalahan dalam pembelajaran Statistik di PGMI Unipdu Jombang, antara lain: (1) hasil belajar statistik sebagian besar mahasiswa rendah, (2) hasil belajar pada Ulangan Tengah Semester sebelumnya rendah, mahasiswa yang mampu mencapai keberhasilan hanya 52\%, (3) diperlukan metode/pendekatan yang tepat untuk menumbuhkan minat dan aktivitas mahasiswa.

Mahasiswa akan merasa jenuh mendengarkan materi yang disampaikan oleh dosen, sehingga menyebabkan materi tidak terserap dan tidak tersimpan dengan baik di memori mahasiswa. Kejenuhan mahasiswa mengakibatkan rendahnya tingkat keaktifan mahasiswa untuk melibatkan dirinya dalam proses belajar mengajar dan dapat mempengaruhi motivasi mahasiswa untuk belajar sehingga rasa ingin tahu mahasiswa menjadi lebih rendah.

Statistik sebagai sebuah mata kuliah dalam menguasainya dibutuhkan pemahaman dan kemampuan cara representasi yang berbeda-beda atau multi representasi untuk konsep yang sedang dipelajari. Multi representasi merupakan salah satu pendekatan yang baik dan sedang berkembang untuk menanamkan pemahaman konsep, penyelesaian suatu masalah dan kesulitan yang disebabkan karena banyaknya keterlibatan gambaran mental (David dkk., 2013; Nieminen dkk., 2013; Bryce, 2012).

Pada penelitian ini, peneliti memilih pendekatan keterampilan multi representasi dengan alasan, pendekatan keterampilan multi representasi ini sangat sesuai dipakai dengan materi-materi statistik yang berkaitan dengan permasalahan dalam kehidupan sehari-hari. Sehingga mahasiswa tidak merasa jenuh dalam belajar statistik, oleh karena itulah dosen harus mengambil tindakan yang dapat meningkatkan peran aktivitas mahasiswa untuk mendukung terlaksanakannya proses pembelajaran yang menarik dan bermakna. Oleh karena itu, penulis melakukan penelitian untuk mengetahui bagaimana pengaruh pembelajaran statistik dengan pendekatan keterampilan multi representasi terhadap hasil belajar mahasiswa PGMI Unipdu Jombang.

\section{KAJIAN TEORI}

Penelitian Kohl \& Finkelstein $(2008 ; 2007)$ menyatakan bahwa peserta didik membutuhkan bimbingan ketika tahap penyelesaian masalah menggunakan multi representasi dalam membangun deskripsi verbal, visual, dan matematis pada kegiatan penyelidikan dalam pembelajaran. Peserta didik harus memperoleh pemahaman konsep dan membutuhkan kegiatan pembelajaran yang dapat menyajikan konsep yang mereka miliki secara utuh dengan multi representasi (Nieminen dkk, 2011; Cook, 2006; De Jong, dkk., 2010; Larkin \& Simon, 1987; Meij \& Jong, 2006).

Kohl \& Finkelstein (2008) menjelaskan bahwa untuk mengetahui peserta didik masih pemula atau sudah ahli dalam menyelesaikan masalah dengan multi representasi dapat dievaluasi dengan dua cara, yaitu: 1) pendidik menyediakan permasalahan dalam pembelajaran disertai petunjuk yang dapat digunakan peserta didik untuk menyelesaikan permasalahan tersebut secara multi representasi; 2) peserta didik harus menyelesaikan permasalahan tersebut dengan keterampilan multi representasi mereka sendiri tanpa petunjuk dari pendidik.

Salah satu kemampuan yang dikembangkan di abad-21 adalah kemampuan komunikasi dan kolaborasi yang dapat dicapai dengan penggunakan multi media dan teknologi linguistik yang berfokus pada oral dan teks tertulis sering dianggap 
sebagai kunci model komunikasi, model lain seperti visual mempunyai peran yang penting dalam proses belajar dan mengajar (Trilling, 2009; Kress dkk., 2001). Belajar menggunakan multi representasi memberikan peluang terjadinya pembentukan makna pada kerja memori sehingga peserta didik mengkaitkan antara kata, tabel serta gambar secara simultan (Mayer, 2005; 2003; 2002; 1997).

Penggunaan keterampilan multi representasi berperan penting dalam membantu peserta didik membangun pemahaman dengan lebih mudah dan lebih baik, karena konsep yang kompleks dan luas dapat disajikan lebih sederhana dan holistik (Ainsworth, 2006; 1999; Ainsworth dkk., 2002; Ainsworth \& Loizou, 2003; Ainsworth \& Labeke, 2004).

Penggunaan keterampilan multi representasi memiliki fungsi untuk membantu dosen mengidentifikasi tiga dimensi pembelajaran yang terjadi, yaitu: 1) Representasi memberi peluang kepada dosen untuk dapat menilai pemikiran mahasiswa; 2) Representasi memberi peluang kepada dosen untuk menggunakan teknik pedagogik yang baru; dan 3) Representasi memudahkan dosen untuk menjembatani antara pendekatan pembelajaran konvensional dan pendekatan pembelajaran modern (Cheng dkk., 2009; Izsak \& Sherin, 2003).

Peneliti membatasi dalam penelitian ini, bentuk operasional dari aspek keterampilan multi representasi yang diterapkan dalam pembelajaran statistik seperti pada Tabel 1.

$\underline{\text { Tabel 1. Aspek Keterampilan multi repesentasi pada pembelajaran statistik }}$

\begin{tabular}{|c|c|c|}
\hline \multirow{4}{*}{$\begin{array}{c}\text { Keterampilan } \\
\text { Multi } \\
\text { Representasi } \\
\text { Statistik }\end{array}$} & $\begin{array}{l}\text { Representasi } \\
\text { Statistik }\end{array}$ & Bentuk Operasional \\
\hline & Visual & 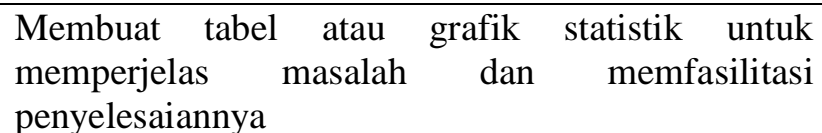 \\
\hline & Matematis & $\begin{array}{l}\text { Menyelesaikan masalah statistik dengan } \\
\text { menggunakan ekspresi matematik }\end{array}$ \\
\hline & Verbal & $\begin{array}{l}\text { Menyelesaikan permasalahan statistik dengan } \\
\text { menggunakan kata-kata atau teks tertulis }\end{array}$ \\
\hline
\end{tabular}

(diadaptasi dari Kohl \& Finkelstein, 2008)

Beberapa alasan pentingnya menggunakan pendekatan multi representasi dalam pembelajaran, yaitu: Multi kecerdasan (multiple intelligences); Visualisasi bagi otak; membantu mengkontruksi representasi tipe lain; Representasi bermanfaat bagi penalaran kualitatif; Representasi matematik digunakan untuk penalaran kuantitatif; Multi representasi bermanfaat dalam kegiatan penyelidikan dalam pembelajaran; Pengetahuan peserta didik menjadi lebih bermakna. (Acevedo dkk., 2010; Etkina, 2010; Rosengrant, dkk, 2009; 2006)

Fungsi utama pendekatan keterampilan multi representasi dalam pembelajaran yaitu: 1) Complement of cognitive (pelengkap proses kognitif) Pendekatan keterampilan multi representasi digunakan untuk memberikan representasi yang berisi informasi pelengkap atau membantu melengkapi proses kognitif. 2) Constrain of interpretation (pembatas interpretasi) Pendekatan keterampilan multi representasi digunakan untuk membatasi kemungkinan kesalahan menginterpretasi dalam menggunakan representasi yang lain. 3) Construct of knowledge (pembangun pemahaman) Pendekatan keterampilan multi representasi digunakan untuk mendorong peserta didik membangun pemahaman 
konsep dalam pembelajaran secara mendalam. (Ainsworth, 2006; 1999; Ainsworth dkk., 2002; Ainsworth \& Loizou, 2003; Ainsworth \& Labeke, 2004).

\section{METODE}

Metode penelitian adalah teknik atau cara yang ditempuh oleh peneliti dalam melakukan penelitian. Teknik dan cara yang dilakukan antara lain menentukan sasaran penelitian dan dilanjutkan dengan penyusunan rancangan penelitian, metode pengumpulan data, dan metode analisis data.

Jenis penelitian yang dilakukan adalah penelitian eksperimental. Tujuan dari penelitian eksperimental ini untuk menyelidiki kemungkinan saling hubungan sebab akibat dengan cara mengenakan satu atau lebih kelompok eksperimental satu atau lebih kondisi perlakuan dan membandingkan hasilnya dengan satu atau lebih kelompok kontrol yang dikenai kondisi perlakuan (Suryabrata, 2003:29).

Populasi penelitian adalah mahasiswa PGMI Unipdu Jombang. Penelitian ini dilaksanakan di PGMI Unipdu Jombang pada semester ganjil bulan Oktober sampai bulan Desember 2014. Sedangkan sampel penelitian diambil secara random sampling, yaitu mahasiswa PGMI Unipdu Jombang semester 3.

Penelitian ini menggunakan rancangan "one group pretest-posttest design", di mana digunakan satu kelompok subyek. Pertama-tama dilakukan uji awal, lalu dikenakan perlakuan untuk jangka waktu tertentu, kemudian dilakukan uji akhir (Fraenkel, Jack R., 2009: 265). Rancangan penelitian dapat digambarkan pada Tabel 2.

Tabel 2. Rancangan Penelitian

\begin{tabular}{rrc}
\hline Pre test & Perlakuan & Post test \\
\hline $\mathrm{O}_{1}$ & $\mathrm{X}$ & $\mathrm{O}_{2}$
\end{tabular}

Sumber : Fraenkel, Jack R. (2009: 265)

Hasil penelitian yang diperoleh berupa nilai pre test dan nilai post test. Pre test diberikan pada kelompok eksperimen sebelum diberi treatment oleh peneliti, dan post test diberikan pada kelompok eksperimen setelah mendapat treatment. Soal pre test dan soal post test yang diberikan berbeda.

\section{HASIL DAN PEMBAHASAN}

Hasil belajar mahasiswa PGMI Unipdu Jombang semester 3 dapat dilihat melalui deskripsi analisis perhitungan statistik berikut ini.

Tabel 3. Paired Samples Statistics kelas PGMI 3

\begin{tabular}{llllll}
\hline & Mean & N & $\begin{array}{l}\text { Std. } \\
\text { Deviation }\end{array}$ & $\begin{array}{l}\text { Std. Error } \\
\text { Mean }\end{array}$ \\
\hline Kelas & Sesudah diberikan & 92,3485 & 3 & 4,28202 &, 74540 \\
PGMI & $\begin{array}{l}\text { Pendekatan Keterampilan } \\
3\end{array}$ & & 3 & & \\
& $\begin{array}{l}\text { multi representasi } \\
\text { Sebelum diberikan }\end{array}$ & 34,8485 & 3 & 12,35762 & 2,15119 \\
& $\begin{array}{l}\text { Pendekatan Keterampilan } \\
\text { multi representasi }\end{array}$ & & 3 & & \\
\hline
\end{tabular}

Sumber: Hasil Analisis SPSS v.18 
Tabel 3. Paired samples statistic memuat deskriptif tentang hasil belajar statistik mahasiswa PGMI semester 3 antara sebelum dan sesudah diberikan Pendekatan Keterampilan multi representasi yang meliputi banyaknya data, mean, standar deviasi dan standar error mean. Banyaknya data $(\mathrm{N})$ masing-masing mahasiswa antara yang sebelum dan sesudah diberikan Pendekatan Keterampilan multi representasi adalah 33 mahasiswa PGMI semester 3, rata-rata (mean) hasil belajar statistik mahasiswa PGMI semester 3 sebelum diberikan Pendekatan Keterampilan multi representasi sebesar 34,8485; dan rata-rata (mean) hasil belajar statistik mahasiswa PGMI semester 3 sesudah diberikan Pendekatan Keterampilan multi representasi sebesar 92,3485, simpangan baku (standar deviasi) masing-masing untuk yang sebelum diberikan Pendekatan Keterampilan multi representasi sebesar 12,35762; dan sesudah diberikan Pendekatan Keterampilan multi representasi sebesar 4,28202; sedangkan untuk standar of mean masing-masing untuk yang sebelum diberikan Pendekatan Keterampilan multi representasi sebesar 2,15119; dan sesudah diberikan Pendekatan Keterampilan multi representasi sebesar 0,7454 .

Berdasarkan perbandingan rata-rata (mean) hasil belajar statistik sebelum diberikan Pendekatan Keterampilan multi representasi sebesar 34,8485; dan sesudah diberikan Pendekatan Keterampilan multi representasi sebesar 92,3485. Hal itu berarti terdapat peningkatan yang signifikan hasil belajar statistik mahasiswa PGMI semester 3 dalam pembelajaran statistik menggunakan Pendekatan Keterampilan multi representasi.

Tabel 4. Paired Samples Correlations kelas PGMI 3

\begin{tabular}{lllll}
\hline & & N & Correlation & Sig. \\
\hline Kelas & $\begin{array}{l}\text { Sesudah dan sebelum diberikan } \\
\text { pendekatan Keterampilan Multi } \\
\text { Representasi }\end{array}$ & 33 &, 274 &, 123 \\
\hline
\end{tabular}

Sumber: Hasil Analisis SPSS v.18

Tabel 4. paired sample correlation, memuat data tentang ada tidaknya korelasi hasil belajar statistik mahasiswa PGMI semester 3 sebelum dan sesudah diberikan Pendekatan Keterampilan multi representasi, diperoleh korelasi sebesar 0,274 yang menunjukkan bahwa adanya hubungan antara hasil belajar statistik mahasiswa PGMI semester 3 sebelum dan sesudah diberikan Pendekatan Keterampilan multi representasi.

Tabel 5. Paired Samples Test Kelas PGMI 3

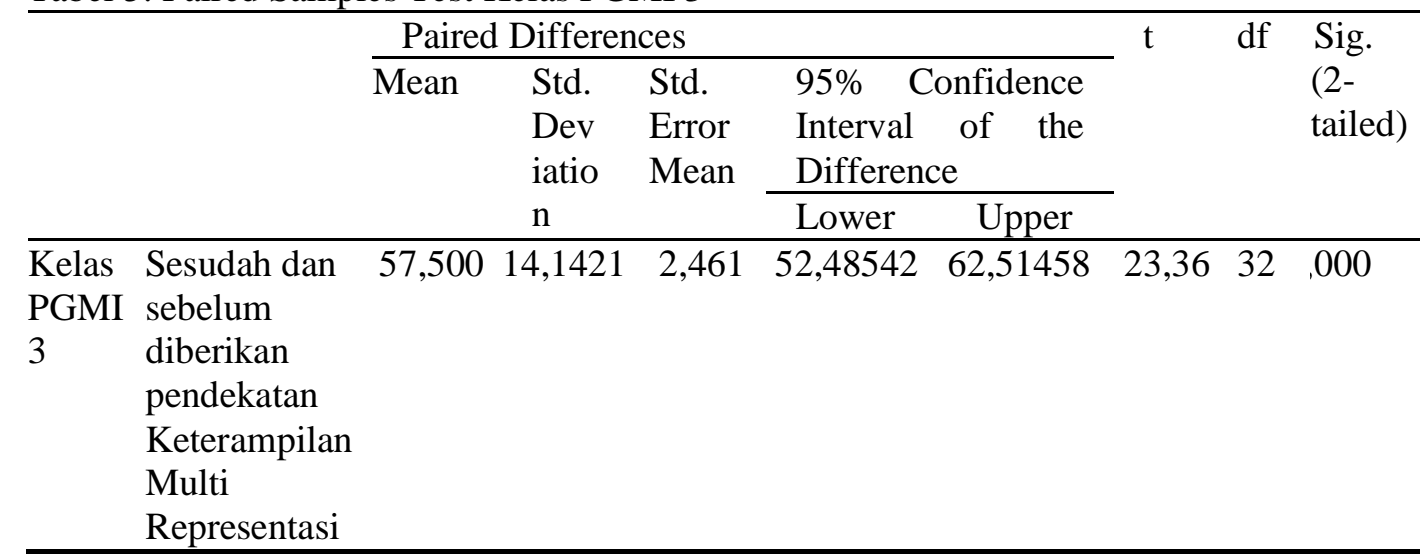

Sumber: Hasil Analisis SPSS v.18 
Tabel 5. Paired sample test di atas, memuat data hasil analisis Uji t dua sampel berpasangan yang meliputi t hitung dan signifikansi.

Hipotesis penelitian:

Ho : Tidak terdapat pengaruh hasil belajar statistik mahasiswa PGMI semester 3 antara sebelum dan sesudah diberikan Pendekatan Keterampilan multi representasi.

H1 : Terdapat pengaruh hasil belajar statistik mahasiswa PGMI semester 3 antara sebelum dan sesudah diberikan Pendekatan Keterampilan multi representasi.

Berdasarkan data di atas maka dapat dilakukan pengujian hipotesis dengan cara sebagai berikut:

Jika t hitung > t tabel, maka Ho ditolak, dan $\mathrm{H} 1$ diterima

Jika t hitung < t tabel, maka Ho di terima, dan H1 ditolak

Untuk melihat harga t tabel maka didasarkan pada derajat kebebasan (dk), yang besarnya adalah $\mathrm{N}-1$,yaitu 33-1 = 32, berdasarkan hasil analisis uji t dua sampel berpasangan, maka dapat diperoleh hasil sebagai berikut:

Tabel 6. Hasil Analisis Uji T

\begin{tabular}{llcc}
\hline Kelas & $\mathrm{N}$ & $\mathrm{t}_{\text {hitung }}$ & $\mathrm{t}_{\text {tabel, }} \alpha=0,05$ \\
\hline PGMI 3 & 33 & 23,36 & 2,0404 \\
\hline
\end{tabular}

Berdasarkan hasil analisis uji $\mathrm{t}$ dua sampel berpasangan, maka dapat diperoleh hasil sebagai berikut: Jadi T hitung > T tabel, maka Ho ditolak, dan H1 diterima. Artinya bahwa terdapat pengaruh hasil belajar statistik mahasiswa PGMI semester 3 antara sebelum dan sesudah diberikan Pendekatan Keterampilan multi representasi.

Dari uji hipotesis yang telah dilakukan tersebut dapat diketahui bahwa nilai $t_{\text {hitung }}$ di luar interval $t_{\text {tabel }}(\alpha=0,05)$ maka dapat dikatakan bahwa Ho ditolak dan $\mathrm{H} 1$ diterima. Dengan melihat hasil uji hipotesis maka dapat dikatakan bahwa ada pengaruh hasil belajar statistik mahasiswa PGMI semester 3 antara sebelum dan sesudah diberikan Pendekatan Keterampilan multi representasi. Pembelajaran dengan menggunakan Pendekatan Keterampilan multi representasi ternyata menghasilkan nilai rata-rata kelas yang lebih tinggi dibandingkan nilai rata-rata kelas yang pembelajaran tidak menggunakan Pendekatan Keterampilan multi representasi. Dengan kata lain mahasiswa yang mendapatkan pembelajaran dengan Pendekatan Keterampilan multi representasi mempunyai hasil belajar lebih baik dibandingkan dengan mahasiswa yang tidak mendapatkan pembelajaran dengan Pendekatan Keterampilan multi representasi.

Berdasarkan daftar nilai hasil belajar dilihat rata-rata hasil belajar mahasiswa pada tabel sebagai berikut:

Tabel 7. Nilai Rata-Rata Hasil belajar statistik mahasiswa PGMI semester 3

\begin{tabular}{ccc}
\hline \multirow{2}{*}{ Kelas } & \multicolumn{2}{c}{ Nilai rata-rata } \\
\cline { 2 - 3 } & Pre test & Post test \\
\hline Kelas PGMI 3 & 34,8 & 92,3 \\
\hline
\end{tabular}


Penelitian pada uji awal sebanyak 32 mahasiswa tidak tuntas dengan ratarata $34,8 \%$. Proporsi ketuntasan uji akhir yang dicapai semua mahasiswa tuntas $100 \%$ dengan rata-rata $92,3 \%$. Jadi prosentase ketuntasan mahasiswa pada uji awal dan uji akhir meningkat dari 34,8\% menjadi $92,3 \%$.

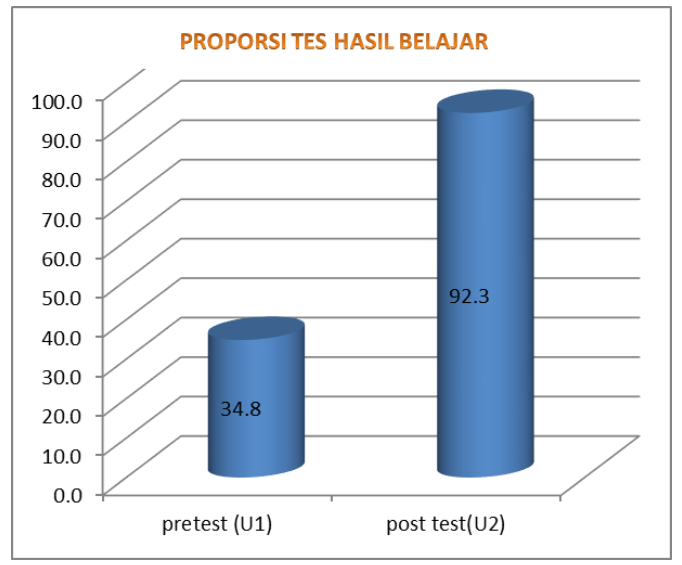

Gambar 1. Grafik Proporsi Ketuntasan Tes Hasil Belajar Statistik Mahasiswa PGMI Semester 3 pada U1 (Uji Awal) dan U2 (Uji Akhir)

Rata-rata hasil tes belajar statistik mahasiswa PGMI semester 3 sesudah diajar dengan Pendekatan Keterampilan multi representasi lebih tinggi daripada rata-rata hasil belajar sebelum diajar dengan Pendekatan Keterampilan multi representasi. Dengan kata lain, terjadi peningkatan hasil belajar mahasiswa setelah diberi pembelajaran dengan menggunakan Pendekatan Keterampilan multi representasi.

\section{SIMPULAN DAN SARAN}

Berdasarkan analisis uji t sampel berpasangan dapat disimpulkan bahwa terdapat pengaruh hasil belajar statistik mahasiswa PGMI semester 3 antara sebelum dan sesudah diberikan Pendekatan Keterampilan multi representasi. Berdasarkan perbandingan rata-rata (mean) disimpulkan bahwa hasil belajar statistik mahasiswa PGMI semester 3 sesudah diberikan Pendekatan Keterampilan multi representasi lebih tinggi daripada sebelum diberikan Pendekatan Keterampilan multi representasi. Hal itu berarti terdapat peningkatan yang signifikan hasil belajar statistik mahasiswa PGMI semester 3 sesudah diberikan Pendekatan Keterampilan multi representasi. Maka, ini berarti Pendekatan Keterampilan multi representasi sangat efektif dalam meningkatkan hasil belajar statistik mahasiswa PGMI semester 3 di Unipdu Jombang.

Berdasarkan kesimpulan tentang hasil belajar yang telah dicapai dengan Pendekatan Keterampilan multi representasi, maka pendekatan pembelajaran ini dapat dijadikan alternatif untuk diterapkan di institusi pendidikan yang berbeda pada materi yang relevan dan dapat sebagai rujukan bagi penelitian lanjutan yang relevan dengan penelitian ini. 


\section{DAFTAR RUJUKAN}

Acevedo, N. A., Van Dooren, W., Clarebout, G., Elen, J., and Verschaffel, L. (2010). Representational Flexibility in Linear Function Problems: A Choice/No-Choice study. In L. Verschaffel, E. De Corte, T. de Jong and J. Elen (Eds.) Use or Representations in Reasoning and Problem Solving: Analysis And Improvement. Milton park, UK: Routledge, 74-93.

Ainsworth, S. (1999). The Function Of Multiple Representations. Computers and Education, 33, 131-152.

Ainsworth, S. (2006). DeFT: A Conceptual Framework For Considering Learning With Multiple Representations. Learning and Instruction. 16 (3), 183-198.

Ainsworth, S., Bibby, P., and Wood, D. (2002). Examining The Effect of Different Multiple Representational System in Learning Primary Mathematics. The Journal of The Learning Sciences, 11, 25-61.

Ainsworth, S., and T. Loizou A. (2003). The Effect of Self Explaining When Learning with Text or Diagram. Cognitive Science, 27, 669-681.

Ainsworth, S., and Van Labeke, N. (2004). Multiple Form of Dinamic Representation. Learning and Instruction, 14, 241-255

Ainsworth, S. (2006). DeFT: A Conceptual Framework For Considering Learning With Multiple Representations. Learning and instruction. 16 (3), 183-198.

Bryce, D. (2012). Scaffolding in Teaching Knowledge Representation. CCSC: Rocky Mountain Conference. Utah State University Departement Computer Science.

Cheng, M. and Gilbert. (2009). Towards a Better Utilization of Diagram in Research into the Use of Representative Levels in Chemical Education. Model and Modeling in Science Education Multiple Representation in Chemical Education. Springer Science \& Business Media B.V. p.55-73.

Cook, M. (2006). Visual Representations in Science Education: The Influence of Prior Knowledge and Cognitive Load Theory on Instructional Design Principles. Science Education, 90(6), 1073-1091

David, M.J. dkk. (2013). The Effect of Representation on Difficulty Perception and Learning of the Physical Concept of Pressure. Themes in Science and Technology Education. 6(2), 91-108.

De Jong, T. (2010). Cognitive Load Theory, Educational Research, and Instructional Design: Some Foof for Throught. Instructional Science, 38, 105-134.

Etkina, E. (2010). Scientific Abilities and Their Assesment. Physical Review Special Topics- Physics Education Research, 2, 100-113

Fraenkel, Jack R., (2009). How to design and evaluate research in education $7^{\text {th }}$. McGraw Hill Companies, Inc: New York.

Izhak and Sherin, M. G. (2003). Exploring the Use of New Represetation as a Resource for Teaching Learning. The University of Georgia and North Western University, Journal School Science and Mathematics. 103, (1).

Kohl, P.B., and Noah, D. F. (2007). Strongly and Weakly Directed Approach to Teaching Multiple Representation Use in Physics. Physical Review Spesial Topics-Physics Education Research, 3, 010108

Kohl, P.B., and Noah, D. F. (2008). Patern of Multiple Representation Use by Expert and Novices During Physics Problem Solving. Physical Review Spesial Topics- Physics Education Research, 2, 010102 
Kress, G. Jewitt, C., Ogborn, J., Tsatsarelis, C. (2001). Exploring Learning Through Visual, Actional and Lingustic Communication: the multimodal environment of a science classroom. Educational Review, Vol 53, No.1.

Larkin, J., and Simon, H. (1987). Why a Diagram is (Sometimes) Worth Ten Thousand Words. Cognitive Science, 11(1) 65-99.

Mayer, R. (1997). Multimedia Learning: are We Asking The Right Questions. Educational Phychologist, 32, 1-19

Mayer, R. (2001). Multimedia Learning. New York: Cambridge University Press.

Mayer, R. (2003). The Promise of Multimedia Learning: Using The Same Instructional Design Methods Across Different Media. Learning and Instruction, 13, 125-139.

Mayer, R. (2005). The Cambridge Handbook of Multimedia Learning. Cambridge: Cambridge University Press.

Meij, J., and Jong, T. (2006). Supproting Student's Learning with Multiple Representations in a Dynamic Simulation-Based LearningEnvironment. Learning and Instruction, 16(3), 199-212.

Meij, J., and Jong, T. (2007). Learning with Multiple Representations. Paper presented at the EARLI Conference, 26 August 2007, Padua, Italy.

Nieminen, P, Savainainen, A., and Viiri, J. (2010). Force Concept Inventory Based Multiple-Choice Tets for Investigating Students' Representational Consistency. Physical Review Spesial Topics- Physics Education Research 6(2), 020109

Nieminen, P, Savainainen, A., Nurkka, N. and Viiri, J. (2011). An Intervention for Using Multiple Representation of mechanics in Upper Secondary School Courses, in Proceedings of the ESERA (2011) Conference, Lyon (2011). Edited by C. Brugutere, A. Tiberghein, and P. Clement.

Nieminen, P, Savainainen, A., and Viiri, J. (2012). Relations Between Representational Consistency, Conceptual Understanding of The Force Concept, and Scientific Reasoning. Physical Review Spesial Topics- Physics Education Research 8(1), 2, 010123

Nieminen, P, et al., (2013). Representational Consistency and the Learning of Forces in Upper Secondary school physics. Jyvâskylâ: Jyvâskylâ University Printing House.

Rosengrant, D., Van Heuvelen, A., and Etkina, E. (2006). Two Year Study on Students' use of Free-Body Diagrams. NARST Annual Meeting, San Fransisco, CA.

Rosengrant, D., Van Heuvelen, A., and Etkina, E. (2009). Do Students use and Understand free-body diagrams?. Physical Review Spesial Topics- Physics Education Research, 5(1), 010108.

Schnotz, W., and Bannert, M. (2003). Construction and Interference in Learning from Multiple Representation. Learning and Instruction, 13(2).

Schnotz, W., and Lowe, R. (2003). Special Issue Introduction: External and Internal Representations in Multimedia Learning. Learning and Instruction. 13, 177-123.

Schnotz, W., and Lowe, R. (2010). External and Internal Representations in Multimedia Learning. Learning and Instruction, 13, 177-123. 
Schnotz. W. Baadte, C., Müller, A., and Rasch, R. (2010). Creative Thinking and Problem Solving with Depictive and Descriptive Representations. In L. Verschaffel, E. De Corte, T. de Jong and J. Elen (eds), Use of Represtations in Reasoning and Problem Solving: Analysis and Improvement (p. 11-35). Milton Park, UK: Routledge.

Slavin, R. E. (1994). Educational Psychology : Theory Into Practice. Boston: Allyn and Bacon Publisher.

Suryabrata, Sumadi. (2003). Metodologi Penelitian. Jakarta : PT Raja Grafindo

Trilling, B. and Fadel, C. (2009). $21^{\text {st }}$ Century Skills: Learning For Life In Our Times. Jossey-Bass. 